\title{
DEZVOLTAREA UNUI COMPLEX MOBIL PENTRU REPRODUCEREA ECOLOGO-INDUSTRIALĂ A SPECIILOR PELAGOFILE DE PEȘTI ÎN CONDIṬII DE FLUVII ȘI LACURI
}

\author{
Oleg Crepis, Dumitru Bulat, Elena Zubcov, Marin Usatiii, \\ Denis Bulat, Nicolae Șaptefrați, Aureliu Cebanu
}

\author{
Institutul de Zoologie, e-mail: o.krepis@mail.ru
}

\section{Rezumat}

Populațiile celor mai multe specii de pești din Republica Moldova se reproduc natural, cu toate acestea, ca urmare a impactului antropic tot mai accentuat asupra ecosistemelor acvatice, condițiile pentru reproducerea lor naturală s-au deteriorat semnificativ. În acest context, unul dintre obiectivele de cercetare pentru anul 2020 a fost elaborarea principiilor tehnologice eficiente de conservare și valorificare rațională a fondului piscicol autohton. S-a stabilit că asigurarea dezvoltării celor mai vulnerabile etape din ontogeneza peștilor în condiții de mediu controlate este un principiu de bază al managementului productivității populațiilor de scrumbie-de-Dunăre. Pentru realizarea în practică a principiilor de gestionare a productivității loturilor de reproducători, a fost elaborată o instalație mobilă pentru reproducerea speciilor pelagofile de pești.

Cuvinte-cheie: populații de pești, specii pelagofile, reproducători, fond piscicol, instalație mobilă de reproducere

\section{INTRODUCERE}

Populațiile celor mai multe specii de pești din Republica Moldova se reproduc pe cale naturală, cu toate acestea, ca urmare a impactului antropic tot mai evident asupra ecosistemelor acvatice, condițiile pentru reproducerea lor naturală s-au deteriorat semnificativ (perturbarea regimului hidrologic, poluarea zonelor de reproducere (boiștilor) și a locurilor de îngrășare a puietului, scăderea aprovizionării trofice). Există două direcții principale pentru menținerea productivității normale a ihtiofaunei - îmbunătătirea condițiilor de reproducere naturală a speciilor de pești și reproducerea artificială a acestora, în cazul în care condițiile de reproducere naturală nu pot fi corectate.

În procesul colectării informației cu privire la influența schimbărilor condițiilor climaterice asupra eficienței reproducerii peștilor pelagofili s-au evidențiat un șir de factori care afectează negativ

https://doi.org/10.53937/9789975151979.13

\begin{abstract}
The populations of most fish species in the Republic of Moldova reproduce naturally, however, as a result of the increasing anthropogenic impact on aquatic ecosystems, the conditions for their natural reproduction have deteriorated significantly. In this context, one of the research objectives for 2020 was the development of efficient technological principles for conservation and rational use of local fish stock. It was revealed the ensuring of the development of the most vulnerable stages in the ontogenesis of fish in controlled environmental conditions is one of the basic principles of productivity management of Danube mackerel populations. In order to put into practice the principles of managing the productivity of breeding stocks, a mobile installation has been developed for the reproduction of pelagophilous fish species.
\end{abstract}

Keywords: fish populations, pelagophilous species, breeders, fish stock, mobile breeding facility

viabilitatea ei la diferite etape ale ontogenezei [5]. Pe baza acestui lucru, am formulat unul din principiile managementului productivității populațiilor de scrumbie: asigurarea dezvoltării celor mai vulnerabile etape din ontogeneza peștilor în condițiile de mediu controlate.

Este cunoscută instalația de reproducere a peștilor [6], realizată sub forma unui doc plutitor cu laturi și având doi pereți perforați longitudinali, formând două rezervoare pentru incubarea icrelor sub formă de canale și despărțitori transversali, situați în tava stației între pereți și formarea între acestea a rezervoarelor pentru creșterea larvelor și alevinilor și a unui rezervor pentru păstrarea reproducătorilor. Dezavantajul instalației constă în aceea că aceasta nu este potrivită pentru reproducerea peștilor pelagofili. Cea mai apropiată după esența tehnică este instalația pentru reproducerea ecologo-industrială de pești pelagofili [4], care conține un bazin cilindric cu 
fundul conic, sistemul de captare a reproducătorilor și sistemul de colectare și incubare a icrelor, Neajunsurile instalatiei constau în faptul că complexul este staționar și este adaptat caracteristicilor obiectivului acvatic țintă.

Pe baza analizei datelor din literatură, una dintre sarcinile cercetării noastre în 2020 a fost "Elaborarea principiilor tehnologice eficiente de conservare și valorificare rațională a fondului piscicol autohton” și în special - „Dezvoltarea unui complex mobil pentru reproducerea ecologo- industrială a speciilor de pești pelagofili în condițiile de fluvii și lacuri”.

\section{METODELE DE CERCETARE UTILIZATE}

Pentru realizarea obiectivelor propuse materialul ihtiologic a fost colectat în aprilie-mai 20162020 în sectorul inferior al fl. Nistru. Prelevarea probelor ihtiologice a fost efectuate $\mathrm{cu}$ ajutorul avelor stationare si plutitoare. La pestii capturati au fost determinate vârsta, sexul, masa corporală și parametrii morfometrici. Colectarea, fixarea, prelucrarea si determinarea materialului ihtiologic a fost realizată în conformitate cu metodele ihtiologice clasice $[1,2,3]$

\section{REZULTATELE OBȚINUTE}

În anul curent pentru realizarea în practică a principiilor de gestionare a productivității loturilor de reproducători a fost elaborată o Instalație mobilă pentru reproducerea peștilor pelagofili.

Instalația reprezintă un doc plutitor, în interiorul căreia sunt amplasate: un sistem de capturare a reproducătorilor, sistemul de reproducere a peștilor, precum și un sistem de colectare și incubare a icrelor după reproducere.

Docul plutitor este format dintr-un corp $1 \mathrm{cu}$ fundul plat 2 , părțile laterale 3 , pontoane 4 , traverse 5 și grătar de reținere a impurităților 6. În partea anterioară a corpului 1 sunt prevăzute porți orizontale dreptunghiulare 7 ataşate la fundul plat 2 cu posibilitatea de rotație în jurul axei orizontale. Grătarul de reținere a impurităților 6 este format din rame de plasă dreptunghiulare 8 , o bară orizontală 9 de formă trapezoidală, atașată de fundul plat 2 cu o bază largă spre exterior și bare verticale 10 atașate la ea, formând orificii pentru montarea ramelor dreptunghiulare din plasă 8 , pentru fixarea cărora, de-a lungul perimetrului orificiilor sunt prevăzute șine perechi 11.La pupa docului plutitor, este prevăzut un gard de furajare 12 , format din clape dreptunghiulare perforate 13 , clape neperforate 14 , o bară orizontală 15 de formă trapezoidală, plasată la fundul stației 2 cu o bază largă în interior și bare verticale 16 atașate la acesta, formând orificii pentru instalarea clapelor dreptunghiulare 13 sau 14, pentru fixarea cărora pe perimetrul orificiilor sunt prevăzute șine perechi 17 .

Sistemul de capturare a reproducătorilor constă dintr-un compartiment 18 pentru colectarea reproducătorilor din obiectivul acvatic, conectat cu acesta printr-o fereastră 19 cu clapetă 20 și un dispozitiv pentru deplasarea reproducătorilor, instalat atât în obiectivul acvatic, cât și în compartimentul respectiv 18. Dispozitivul pentru deplasarea reproducătorilor are forma unei capcane din plasă de tipul năvodului staționar, constând dintr-un ghidaj central 21 din pânză de plasă și ghidaje laterale 22 din pânză de plasă, precum și porți din plasă 23 care se deschid în compartimentul 18 pentru colectarea reproducătorilor printr-o fereastră 19 cu clapeta 20 pentru a facilita deplasarea în compartimentul 18 și este echipat cu surse de propagare a radiațiilor fizice 24 (luminoase, acustice, electrice etc.) pentru a atrage peștii în compartimentul 18.

Sistemul de reproducere a peștilor conține un bazin cilindric $25 \mathrm{cu}$ fundul conic 26 , un orificiu central de scurgere 27 și o țeavă de evacuare perforată verticală 28 fixată în acesta, precum și canale 29 care conectează compartimentul 18 de colectare a reproducătorilor cu bazinul cilindric 25 , precum și compartimentul cu pompe 30. Partea cilindrică a bazinului 25 este formată dintr-o grindă poligonală orizontală 31 , fixată de-a lungul marginii superioare a fundului conic 26 și bare verticale 32 care pleacă de la acesta, formând orificii dreptunghiulare, de-a lungul perimetrului cărora sunt atașate șine 33 pentru fixarea clapelor neperforate dreptunghiulare 34 sau a ramelor dreptunghiulare $35 \mathrm{cu}$ jaluzele verticale $36 \mathrm{cu}$ decalaj reglabil. Compartimentul cu pompe de apă 30 reprezintă o cutie dreptunghiulară 37 , atașată de una dintre laturile sale deschise din exterior la una dintre orificiile bazinului 25, închisă de o ramă 35 cu jaluzele 36 .

Sistemul de colectare și incubare a icrelor după reproducere include un bazin dreptunghiular 38 cu un nivel reglabil al apei, țevi 39 de scurgere orizontale, închise de supapele 39a și 39b la intrare și la ieșirea din bazinul 38 și conectate la orificiul de scurgere al bazinului cilindric 25 printr-un receptor cilindric 40 fixat sub acesta, de asemenea, include o pompă 41 pentru pomparea apei din bazinul dreptunghiular 38 și recipienți 42 pentru colectarea și incubarea icrelor. Recipien- 


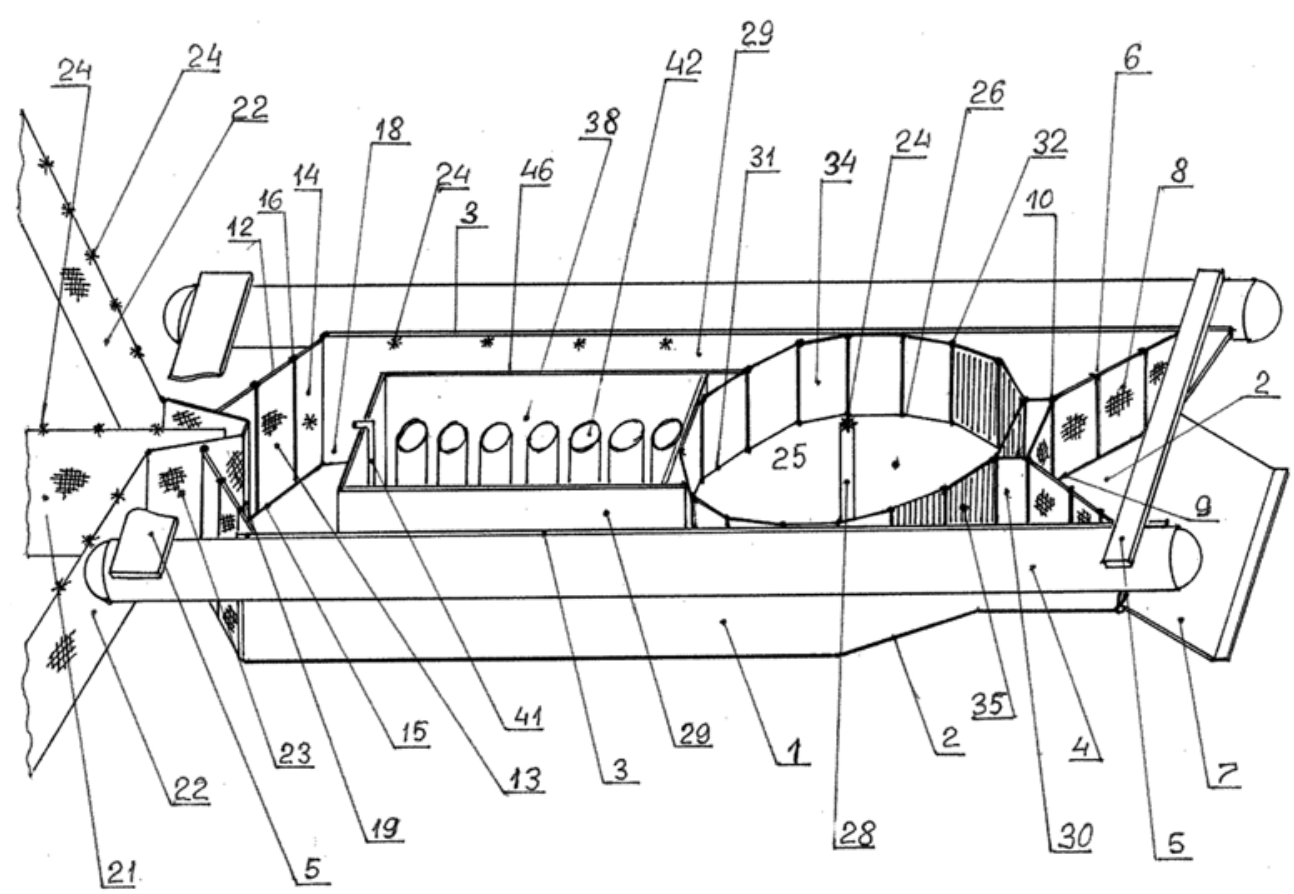

Fig. 1. Instalație mobilă pentru reproducerea peștilor pelagofili, plan axonometric

tele 42 constau dintr-un corp cilindric perforat 43 cu fund conic 44 și o teavă verticală de alimentare cu apă 45 , fixată cu capătul superior în orificiul central al fundului conic 44 si cu capătul inferior conectat printr-un dispozitiv special la o teavă orizontală de scurgere 39. Astfel, pentru fiecare rând de recipiente 42 este prevăzută o țeavă 39 de scurgere orizontală separată. Canalele 29 care conectează compartimentul 18 de colectare a reproducătorilor cu bazinul cilindric 25 sunt formate între pereții laterali 46 ai bazinului dreptunghiular 38 și părțile laterale 3 ale corpului docului plutitor 1 .

Exemplu de realizare a invenției după modelul scrumbiei-de-Dunăre este, că inainte de începerea lucrărilor, dispozitivul este deplasat spre locul caracteristic de reproducere naturală a scrumbiei, fiind fixat în poziție staționară - cu partea anterioară împotriva curentului apei. Ulterior este expusă capcana din plasă de tipul năvodului staționar, îndreptându-se ghidajul central 21 din pânză de plasă pe cursul apei, iar ghidajele laterale 22 din pânză de plasă în direcție radială, de ambele părți perpendicular cursului de apă. Pe pânzele de plasă 21,22 , porțile din plasă 23 , în compartimentul 18 și în canalele 29 sunt plasate sursele de propagare a radiațiilor fizice 24 (pentru scrumbie acestea sunt corpuri de iluminat de culoare albă cu parametri prestabiliți). Pe gardul de furajare 12 se instalează în orificii clapele perforate dreptunghiulare 13, atașate la porțile din plasă 23, iar restul - închid clapele neperforate
14. Clapeta 20 închide fereastra 19, îngrădind accesul peștilor în compartimentul 18. În deschizătoarele grătarelor de reținere a impurităților se instalează ramele de plasă dreptunghiulare 8 , fixându-le în primul rând de șine 11 . Pe măsura impurificării ramelor 8 , ele vor fi substituite cu altele curate, ce vor fi instalate în alt rând de șine. Orificiile bazinului cilindric 25 situate de partea anterioară a corpului instalatiei, sunt închise cu rame dreptunghiulare $35 \mathrm{cu}$ jaluzele verticale 3 ; orificiile bazinului 25 , atasate de canalul 29 , sunt deschise, iar celelalte orificii sunt închise cu clapetele neperforate 34 . Sistema de colectare si incubare a icrelor încă nu este pusă în funcțiune: bazinul dreptunghiular 38 este umplut cu apă, dar pompa 41 este deconectată, supapele 39a și 39b sunt închise si recipientele 42 pentru colectarea si incubarea icrelor fecundate nu sunt instalate. Ulterior, după pregătirea tuturor sistemelor, de pe partea anterioară a corpului instalației 1 , porțile orizontale 7 se închid (cu marginea de sus pe fundul bazinului), servind la direcționarea curentului apei în interiorul instalației. Curentul de apă din râu intră în partea anterioară a corpului 1 a instalației, trece prin grătarele de reținere a impurităților 6 , prin decalajele reglabile ale jaluzelelor verticale 36 ale ramelor dreptunghiulare 35 , și pătrunde în bazinul cilindric 25. Din el curentul apei trece prin orificiile deschise a bazinului 25 în canale 29 și prin ele pătrunde în compartimentul 18 de concentrare a reproducătorilor, iar ulterior, prin porțile de plasă 23 și clapele dreptunghiulare 
perforate 13, apa iese înapoi în râu. După ce reproducătorii de scrubie s-au apropiat de boiști (pe timp de noapte) la porțile de pânză 23 se scoate clapeta 20 , deschizându-se fereastra 19 , și se activează sursele de lumină 24 care vor atrage peștii în compartimentul 18. Becurile de culoare albă se vor conecta cu o anumită periodicitate, dând iluzia de mișcare a luminii într-o singură direcție, în așa fel ghidând reproducătorii spre porțile de plasă 23, prin fereasta 19 în compartimentul 18 , iar apoi în canalele 29 și bazinul cilindric 25 . Elementele constructive ale dispozitivului (capcana din plasă în conbinație cu reflectoarele de lumină s.a.) nu le permite reproducătorilor să iese înapoi în râu și le asigură deplasarea lor liberă în interiorul corpului 1. După concentrarea reproducătorilor de scrumbie în cantități suficiente fereastra 19 se închide cu ajutorul clapetei 20 și se deconectează sursele luminoase 24. În bazinul cilindric 25 jaluzelele verticale 36 pe rame dreptunghiulare 35 se întorc în așa fel, încât curentul de apă ce traversează prin ele să se îndrepte la unul din canalele 29 , generând acolo un curent semnificativ mai mare decât în alt canal. Datorită acestui fapt, peștii din compartimentul 18 (orientându-se împotriva curentului mai puternic de apă) intră în acest canal, iar prin el nimeresc în bazinul 25, înoată o perioadă oarecare în curentul de apă, iar apoi, se întorc pe celălalt canal 29 înapoi în compartimentul 18, și tot așa mai departe, formând mișcări circulare închise. Acest caracter de deplasare a reproducătorilor imită migrația în amonte pe râu, oferind timp gonadelor să atingă maturitatea necesară declanșării reproducerii natural-dirijate.

Atunci când peștii încep a demonstra semne de pregătire către actul reproductiv, în dispozitiv se efectuează următoarele manipulări. În bazinul cilindric 25 la început se închid cu clapetele neperforate 34 orificiile ce contactează cu canalul 29, prin intermediul căruia peștii nimeresc în compartimentul 18. Ulterior, după ce peștii, deplasându-se împotriva curentului de apă pe canalul 29 , se vor concentra în bazinul cilindric 25 , deschizăturile ce contactează cu canalul 29 , de asemenea se vor închide prin intermediul clapetelor neperforate 34, și peștii în așa fel, rămân izolați în bazinul 25. Concomitent cu aceste acțiuni se închid jaluzelele verticale de pe rame 35 (înafara de rama, atașată la cutia dreptunghiulară 37), se deschid supapeele 39a și 39b de pe țevile orizontale de evacuare și se pun în funcțiune pompele 30 , care vor crea în bazinul 25 un curent circular al apei cu parametrii prestabiliți, în care vor îno- ta reproducătorii. Ieșirea apei din bazinul 25 în acest caz se petrece prin orificiile de evacuare 39 în compartimentul 18. Înaintea procesului de reproducere natural-dirijată se pregătește sistemul de colectare și incubare a icrelor fecundate. În bazinul dreptunghiular 38, pe tevile de evacuare 39 se instalează în rând recipientele pentru colectarea icrelor ejaculate. În acest scop recipientul 42 este scufundat în bazinul 38 în așa fel, ca țeava sa verticală de alimentare cu apă 45 să intre și să se conecteze cu țeava de evacuare orizontală 39. După declanșarea reproducerii se închid clapetele $39 \mathrm{~b}$ la toate țevile de evacuare 39 , iar o singură clapetă 39a se lasă deschisă la țeava de evacuare 39. Apoi se pune în funcțiune pompa 41 pentru evacuarea apei din bazinul 38. Astfel, nivelul de apă devine mai mic decât în bazinul 25 și din cauza acestei diferențe de nivele, apa împreună cu icrele fecundate depuse, pătrunde din bazinul 25 prin țeava verticală perforată 28 , orificiul de scurgere 27 și receptorul cilindric 40, în țeava de scurgere orizontală 39 , iar, ulterior prin aceasta, în recipientele 42 de colectare și incubare a icrelor. Surplusul de apă iese din recipientul 42 prin perforațiunile corpului cilindric 43 în bazin 38 . După umplerea, conform parametrilor normativi, a tuturor recipientelor 42 situate într-un rând cu icre fecundate, la țeava de evacuare orizontală 39 ce corespunde acestora, se închid clapetă 39a și se deschid clapetă $39 \mathrm{~b}$ cu scopul preluării apei din compartimentul 18. Acum, apa cu icrele fecundate din bazinul 25 trece într-un alt rând de recipiente 42 prin intermediul altei tevi de evacuare $39 \mathrm{cu}$ supapa deschisă 39a și supapa închisă 39b. După finalizarea procesului reproductiv toate rândurile de recipiente 42 , umplute cu icre, sunt trecute în regim de alimentare cu apă din compartimentul 18 și cu ajutorul supapelor $39 \mathrm{~b}$ se reglează parametrii optimali de incubație.

În aceeași perioadă sunt evacuați reproducătorii din bazinul 25. În acest scop se deconectează pompele 30 și se deschid în bazinul 25 toate jaluzelele cu decalaj de pe ramele 35 , și de asemenea, trecătorile ce contactează cu canalele 29. Pe lângă acest fapt, la gardul de furajare 12 se scot clapele 13 și 14. În rezultat, curentul de apă ce trece prin sistemul de grătare împinge reproducătorii din bazinul 25 prin canalele 29 în compartimentul 18 iar ulterior prin deschizăturile gardului de furajare 12 - direct în râu. După eliberarea în mediul natural a acestei partide de reproducători de scrumbie-de-Dunăre, procesul de reproducere ecologo-industrială poate fi repetat prin antrenarea altui grup de reproducători în dispozitiv. 


\section{CONCLUZII}

Esența invenției constă în faptul că se propune o instalație, care reprezintă un doc plutitor cu baraj de reținere a impurităților și pompe submersibile cu flux direct, în interiorul căruia sunt amplasate: sistemul de capturare a reproducătorilor, sistemul de reproducere a pestilor, precum si un sistem de colectare și incubare a icrelor după reproducere, caracterizată prin faptul că:

1) La capătul docului plutitor sunt prevăzute porți orizontale dreptunghiulare, fixate de fundul acestuia cu posibilitatea de rotire în jurul axei sale orizontale; gardul de reținere a impuritătilor este format din rame dreptunghiulare din plasă, o bară trapezoidală orizontală amplasată la fundul stației, cu baza mai largă spre exterior și bare verticale fixate de acesta, care formează orificii pentru montarea ramelor dreptunghiulare din plasă, iar pe perimetrul orificiilor sunt instalate șine perechi pentru fixarea lor; la pupa docului plutitor este prevăzut un gard de furajare, format din clape dreptunghiulare neperforate și perforate, o bară trapezoidală orizontală situată la fundul docului cu o bază largă spre interior și bare verticale fixate de acesta, care formează orificii pentru montarea clapelor dreptunghiulare, iar pe perimetrul orificiilor sunt instalate șine perechi pentru fixarea lor.

2) În sistemul de capturare a reproducătorilor, instalația pentru deplasarea reproducătorilor se prezintă ca o capcană din plasă de tipul năvodului staționar, alcătuită din ghidaj central și laterale din pânză de plasă, precum și porți din plasă care se deschid în compartimentul pentru colectarea reproducătorilor printr-o fereastra cu clapă pentru trecerea peștelui și este echipat cu surse de propagare a radiațiilor fizice (luminiscente, acustice, electrice, etc.) pentru atragerea peștilor în compartimentul.

3) Sistemul de reproducere a peștilor include, de asemenea, canale care conectează compartimentul pentru colectarea reproducătorilor $\mathrm{cu}$ bazinul cilindric; partea cilindrică a bazinului este formată dintr-o grindă poligonală orizontală, fixată de-a lungul marginii superioare a fundului conic, și grinzi verticale care pleacă de la acesta, formând orificii dreptunghiulare, de-a lungul perimetrului cărora sunt atașate șine pentru fixarea clapelor neperforate dreptunghiulare sau a ramelor dreptunghiulare cu jaluzele verticale cu decalaj reglabil; compartimentul cu pompe reprezintă o cutie dreptunghiulară atașată de una dintre părțile sale deschise în afara bazinului la orificiul dreptunghiular cu o ramă cu jaluzele, iar de alta dintre părțile sale ataşată la orificiul dreptunghiular al gardului de reținere a impurităților cu o ramă de plasă.

4) În sistemul de colectare și incubare a icrelor după depunere, bazinul dreptunghiular este dotat suplimentar cu o pompă pentru evacuarea apei, iar cu pereții săi laterali (împreună cu părțile laterale ale docului) formează canale care conectează compartimentul de colectare a reproducătorilor cu bazinul cilindric, iar țevile de scurgere orizontale sunt prevăzute la fiecare rând de recipiente de colectare și incubare a icrelor și sunt conectate $\mathrm{cu}$ orificiul de scurgere al bazinului printr-un receptor cilindric fixat sub acesta.

Rezultatul tehnic al invenției constă în sporirea eficacității reproducerii naturale a peștilor pe contul elementelor constructive noi a instalaţiei, micșorarea nivelului de stresare și traumatizare a reproducătorilor, asigurarea modelării condițiilor optime de incubație a icrelor embrionate cu o membrană sensibilă și protecția ei de traumatisme, în consecință, majorându-se vitalitatea icrelor embrionate.

Investigațiile au fost realizate în cadrul proiectului 20.80009.7007.06 "Determinarea schimbărilor mediului acvatic, evaluarea migrației și impactului poluanților, stabilirea legităților funcționării hidrobiocenozelor și prevenirea consecințelor nefaste asupra ecosistemelor", finanțat de Agenția Națională pentru Cercetare și Dezvoltare din Republica Moldova.

\section{BIBLIOGRAFIE}

1. Evaluarea stării resurselor piscicole. 2017, 142 p.

2. http://researcharchive.calacademy.org/research/ ichthyology/catalog/fishcatmain.asp (Updated 31 May 2017).

3. Monitoring calității apei și evaluarea stării ecologice a ecosistemelor acvatice. Chișinău, 2015, $84 \mathrm{p}$.

4. Crepis O., Usatîi M., Bulat Dm., Bulat Dn., Șaptefrați N., Usatîi A. 2019. Instalație pentru reproducerea ecologo-industrială a peștilor pelagofili/ patent MD Nr.1418. M kl. A $01 \mathrm{~K}$ 61/00. Institut de Zoologie RM.

5. Крепис О.И., Шарапановская Т.Д., Лобченко В.В. 1999. Современное состояние нерестилищ, среднего и нижнего Днестра и эффективность их использования рыбами// Сохранение биоразнообразия бассейна Днестра. Материалы Международной конференции. Кишинев: Экологическое общество «ВІОТІСА», С.109-111.

6. Малеванчик В. С. 1981. Установка для разведения рыбы. Патент РФ № 839455, Институт «Гидропроект» им. С. Я. Жука. 